\section{The Royal Institution, London}

Ar the annual meeting of the Royal Institution on May 1, the following officers were elected: President, Lord Brabazon of Tara; Treasurer, Mr. W. E. Schall; Secretary, Brigadier H. E. Hopthrow; Managers, Dr. A. Clow, Sir Harold Roxbee Cox, Mr. E. R. Davies, Dr. T. F. Gaskell, Prof. A. G. Gaydon, Prof. Alex. Haddow, Miss E. Henrietta Jebens, Mr. L. B. W. Jolley, Dame Kathleen Lonsdale, Dr. H. Lowery, Mr. Perey H. Sehwarzschild, Mr. W. R. Stevens, Mr. Cyril Sweett, Wing-Commander H. F. Tiarks and Prof. W. D. Wright; Visitors, Mr. A. D. R. Caroe, Mr. Norman Clarke, Miss F. M. Eastwood, Mr. A. H. Ewen, Mr. G. J. Gollin, Mr. F. Greenaway, Mr. C. R. Hopper, Mr. S. Rees Jones, Mr. W. C. Lister, Miss E. Whittall, Mr. F. Poperwell, Dr. A. A. Moss, Dr. H. R. Rishworth, Miss D. Sidebottom and Mr. H. Stanesby.

\section{National Research Council of Canada}

THF following have been appointed members of the National Research Council of Canada for a threeyear term: Prof. F. A. Forward, head of the Department of Mining and Metallurgy, University of British Columbia; Dr. F. K. Hare, dean of the Faculty of Arts and Science, MeGill University; Dr. G. A. Krotkov, head of the Department of Biology, Queen's University at Kingston; and Mr. W. F. McLean, president of Canada Packers, Ltd. Dr. F. R. Hayes, head of the Department of Biology and director of the Oceanographic Institute, Dalhousie University, has been re-appointed to the Council for a further throe-year term. The new appointments fill vacancies caused by the retirement from the Council of Dr. I. Me'Taggart Cowan, University of British Columbia; Dr. A. D. Misener, director of the Ontario Research Foundation; Dr. B. W. Sargent, Queen's University at Kingston; and Dr. D. L. Thomson, MoGill University. Dr. R. J. Uffen, principal of University College, University of Western Ontario, has been appointed to four of the Council's executive committees.

\section{The Night Sky in June}

NEw moon occurs on June 2d. 13h. 27m. U.T. and full moon on June 18d. 02h. 03m. The following conjunctions with the Moon take place: June 5d. $03 \mathrm{~h} .$, Venus $4^{\circ} \mathrm{N}$.; June 21d. 07h., Saturn 0.5 ${ }^{\circ} \mathrm{S}$; June 23d. 12h., Jupiter $2^{\circ}$ N.; June 28d. 10h., Mars $5^{\circ}$ N.; June 29d. 18h., Aldebaran $1^{\circ}$ S.; June 30d. $06 \mathrm{~h}$., Mercury $0 \cdot 8^{\circ} \mathrm{N}$. In addition to these conjunetions with the Moon, Venus is in conjunction with Pollux on June 11d. 19h., Venus being $5^{\circ} \mathrm{S}$. Mercury is too close to the Sun for observation. Venus is an evening star, visible in the west after sunset. It sets at $22 \mathrm{~h} .40 \mathrm{~m} ., 22 \mathrm{~h} .40 \mathrm{~m}$. and $22 \mathrm{~h}$. $25 \mathrm{~m}$. on June 1 , 15 and 30, respectively; its stellar magnitude is -3.4 . Its distance decreases during the month from 127 to 109 million miles and the visible portion of the apparent disk decreases from 0.847 to 0.757 . Mars is still too close to the Sun for easy observation, rising about two hours before the Sun on June 15 . Jupiter rises at $0 \mathrm{~h} .55 \mathrm{~m}$., $0 \mathrm{~h} .00 \mathrm{~m}$. and $23 \mathrm{~h} .00 \mathrm{~m}$, at the beginning, middle and end of the month, respectively. It is in Aquarius, its stellar magnitude is $-2 \cdot 1$ and its distance from the Earth in the middle of the month is $\mathbf{4 4 0}$ million miles. Saturn is in Capricornus, rising at $23 \mathrm{~h}$. $50 \mathrm{~m}$., $22 \mathrm{~h}$. $55 \mathrm{~m}$. and $21 \mathrm{~h}$. $50 \mathrm{~m}$. on June 1,15 and 30 , respectively. Its stellar magnitude is +0.7 and its distance from the Earth on June 15 is 860 million miles. There are no occulta- tions brighter than magnitude 6 visible at Greenwich. The summer solstice occurs on June 2ld. 21 h.

\section{Announcements}

Prof. LÉon VAN Hove, leader of the Theory Division at CERN, has been awarded the Dannie Heineman Prize for mathematical physics by the American Physical Society and American Institute of Physics for his contributions to statistical mechanics and to field theory, as examples of outstanding publication in the field of mathematical physics.

Mr. B. S. Shenstone, a director and chief engineer of British European Airways, has been elected president of the Royal Aeronautical Society for 1962-63. Born in Canada, Mr. Shenstone graduated at the University of Toronto. $\mathrm{He}$ is also vice-chairman of the Society's Man-Powered Aircraft Group Committee.

Mr. Richard HrNole Fowler has been appointed director of the Institute of Applied Science of Victoria, Melbourne. Mr. Fowler, who has been assistant director of the Institute since 1956, succeeds Dr. C. M. Focken, who has retired.

THE annual meeting and summer conference of the Society for Applied Bacteriology will be held in the School of Agriculture, University of Nottingham, during July 17-19. Included in the meeting will be a symposium on "Staphylococci and Micrococci". Further information can be obtained from Dr. Ella M. Barnes, Low Temperature Research Station, Downing Street, Cambridge.

A Two-DAY summer meeting of the Royal Meteorological Society will be held in the University College of North Wales, Bangor, during July 5-6. The programme will include two symposia on "The General Circulation of the Atmosphere" and on "The Electrification of Thunderstorms". Further information can be obtained from the Assistant Secretary, Royal Meteorological Society, 49 Cromwell Road, London, S.W.7.

THE 1962 National Bureau of Standards course in "Radio Propagation" will be held during July 16August 3, 1962. The course, administered by the National Bureau of Standards, Boulder, Colorado, Laboratories, is open to scientific and engineering personnel in other Government agencies, industry, or universities. Further information can be obtained from the National Bureau of Standards Office of Technical Information, U.S. Department of Commerce. Washington 25, D.C.

AN international conference on "The Physics of Semiconductors", arranged by the Institute of Physics and the Physical Society on behalf of the International Union of Pure and Applied Physics and the British National Committee for Physics, will be held in the University of Exeter during July 16-20. Further information can be obtained from the Administration Assistant. the Institute of Physics and the Physical Society, 47 Belgrave Square, London, S.W.1.

Erratum. In the communication entitled "Electron-Diffraction Studies of Fatty-Acid Monolayers", by B. R. Banerjee, B. Ostrofsky and H. E. Ries, jun. (Nature, 193, 873; 1962), lines 14-17 in the second column of p. 874 should read: ". . . to the orientation indicated by the spots. Fig. 4, after collapse at 42 dynes per $\mathrm{cm}$., shows no evidence for orientation; the sharp and continuous diffraction lines suggest random orientation and thicker films". 